Original Research

\title{
Estimation of the Soil Contamination Level of a Large Industrial Centre
}

\author{
Nail C. Minigazimov*, Elnara T. Khaydarshina, Larisa R. Zagitova, \\ Damir N. Kutliyarov, Salavat A. Yunusov
}

Federal State Budgetary Educational Establishment of Higher Education "Bashkir State Agrarian University," Ufa, Russia

Received: 23 September 2020

Accepted: 27 November 2020

\begin{abstract}
Studying the ecological state of soil cover is essential due to its ecological functions in regulating many of the environment's components necessary for the population. The study aims to assess the ecological state and level of soil pollution of the city of Ufa's main functional zones. The study's relevance lies in the fact that Ufa is a large city with dynamically developing industrial production. Still, so far, there have been no systematic studies on the pollution of city soils. Heavy metals, mainly in a diffused state, can form local accumulations, where their concentration is hundreds and thousands of times higher than the average planetary levels. The soil acts as a powerful accumulator of heavy metals and the initial link in the migration of pollutants along the ground trophic chains. A method for studying the level of urban soil pollution presented in this study may be applied in large manufacturing cities.
\end{abstract}

Keywords: heavy metals, hydrocarbons, pollution, urban soils

\section{Introduction}

Soil is a depositing medium capable of accumulating high concentrations of elements. Various anthropogenic (industrial and transport emissions) and natural (soilforming processes) sources affect the composition of soils and their self-restoring ability [1]. The most susceptible to pollution are urban soils with disrupted natural self-cleaning processes. In this regard, it is necessary to monitor urbanized territories' soil cover and identify pollution sources [2].

Among the most critical components, the city's soilplant cover occupies a special place. The soil cover

*e-mail:minigazimovnai@rambler.ru takes on the pressure of the flow of industrial and municipal emissions and waste, acting as a buffer and detoxifier [3]. The soil accumulates heavy metals (HM), pesticides, hydrocarbons, and other chemical pollutants, thereby preventing their entry into other natural environment objects (water bodies, atmospheric air). Other substances in their original or transformed form are bound by the soil's mineral and organic substances, which dramatically reduces their availability to plants [3].

Identified risks to human health due to the release of polycyclic aromatic hydrocarbons into the soil from polluted air in the Yangtze River Delta (China) [4]. Measured the magnetic susceptibility of soils between the rivers Indus and Ganges [5]. Determined the degree of soil contamination in Colombo (Sri Lanka) geological and biological indicators, considers the anthropogenic 
activity to be the primary source $[6,7]$ gave a bioecological assessment of the soils of Annab, which is a major industrial center of Algeria. He considers the reason for the technogenic pollution of soils to be the metallurgical plant Al-Hajar. In the emissions of these plants, heavy metals predominate. The high content of HM was noted in the soils of the Paramo region (Colombia) under the mining industry's influence [8]. A group of Brazilian scientists studied the features of HM's accumulation in roadside soils of Rio de Janeiro [9], related to traffic volume and distance from the highway. The assessment of soil pollution by toxic elements was performed [10] for the southern regions of the capital of Egypt - Cairo. The issue of toxic pollution of soils of the Ojcuv National Park, located near Krakow (Poland) [11] is of interest. The Russian scientists Kasimov et al. [12] calculated the critical loads of benzo(a)pyrene on the soils of the Eastern District of Moscow. Their calculation made it possible to reliably predict soil pollution dynamics and develop measures to clean them. Michael [13] emphasizes the need to manage sulfate-acid soils to reduce agricultural land pollution.

The rationing of HM's maintenance in the soil is severe due to the impossibility of fully considering all the factors determining their concentration and the form of accumulation [14].

To establish the nature of the changes in the soilplant cover's ecological state due to anthropogenic impact, it becomes necessary to organize systematic monitoring of toxicants' content in the soil.

The content of HM in the soil and drinking water has a significant impact on the health of the population, especially in those places where their levels increase due to geochemical and technogenic factors [3].

For a complete study of the situation in Ufa's natural environment and its environs, it seems necessary to conduct studies of the content of pollutants in soils.

Ufa is the Republic of Bashkortostan, one of Russia's largest cities with a population of more than 1,120 thousand people, an important industrial, transport, economic, cultural, and scientific center of the Russian Federation. One of the key branches of the city's industry is oil refining. The city is located on the Belaya river banks (the largest tributary of the Kama River), at the mouth of the Ufa and Dema rivers, near the conditional border between Europe and Asia, one hundred kilometers west the Ural mountains.

Ufa is stretching from the south-west to the northeast for more than 40 kilometers. Ufa's city is located in the Northern forest-steppe zone, which includes the watershed of the Ufa and Belaya rivers and the southern outskirts of the Ufa plateau. The soil distribution within the city is closely related to the nature of the vegetation, the composition of the rocks, climate, topography, and the degree of development of humans' territory. In connection with Ufa's position within the northern and typical forest-steppe, the zonal soil types here are gray and dark gray forest soils, bleached and leached chernozems. The first and second ones are developed mainly on the watersheds, terraces, and gentle slopes of the Belaya River's right bank and elevated relief elements of the left bank, and the latter on the floodplain terraces of the left bank.

\section{Materials and Methods}

The study objects were samples of the surface soil layer of the main functional zones of the city of Ufa in the Kirov, Dema, Lenin, Soviet, October, Ordzhonikidze, Kalinin districts.

Sampling locations are preliminarily marked on a map showing the structure of the urban landscape. The test site should be located in a place typical of the study area $[15,16]$. The most common method for sampling mixed soil samples is the envelope method. In this case, the sampling points are arranged in the form of a sealed envelope (the length of the figure's side can be from 2 to $5-10 \mathrm{~m})$ [17].

Heavy metals were determined by atomic absorption spectrophotometry.

The soil was extracted with carbon tetrachloride, and its content was estimated using a concentrator to determine the petroleum products.

The integrated assessment of the ecological state of soils in Ufa's city was carried out according to the methodology for assessing the level of chemical pollution of soils.

The method's universality is that soil samples' selection and investigation are performed according to Interstate Council for Standardization, Metrology, and Certification [18]. In many countries, identical sampling methods and integrated assessment of the soils' ecological conditions are used.

Soil research was carried out in the Kirov, Lenin, Kalinin, and October districts of Ufa. The control of rural areas is Buzdyak and Kushnarenkovo.

The soils of the territory of the PCE and around them contain heavy fractions of petroleum products with a concentration of $4645.0 \mathrm{mg} / \mathrm{kg}$ (exceeding the background more than 15 times), $\alpha$-methyl styrene $(\alpha-\mathrm{MS})-1.99 \mathrm{mg} / \mathrm{kg}(\mathrm{MAC}-0.5 \mathrm{mg} / \mathrm{kg})$, toluene - $0.78 \mathrm{mg} / \mathrm{kg}(\mathrm{MPC}-0.3 \mathrm{mg} / \mathrm{kg})$, benzene $-0, \mathrm{mg} / \mathrm{kg}$ (0.3 MPC), gasoline $-0.29 \mathrm{mg} / \mathrm{kg}$. Moreover, at a distance of 3-10 km, soil pollution by heavy fractions of petroleum products is significantly less $-194 \mathrm{mg} / \mathrm{kg}$ by more volatile fractions (toluene, benzene, gasoline) - at about the same level.

The dispersion distance of hydrocarbons typical for enterprises is more than $10 \mathrm{~km}$, with the highest content of $\alpha$-methyl styrene in soils at a distance of 1 and $8 \mathrm{~km}$.

\section{Results}

In the summer season of 1991, the Ufa Research Institute of Hygiene and Professional Diseases continued 
to study soil cover in Ufa's same areas. Sampling was carried out in the spring on the residential territory of the city of Ufa and the Ufa region. In June, samples were taken in gardens and orchards.

The average arithmetic concentration of metals is based on the results of $3 \div 7$ combined samples. At first, the results were compared with the MPC value, i.e., the hazard coefficient (K0) was determined, which is the main criterion for the hygienic assessment of the risk of soil pollution with harmful substances.

The lead content in the soil everywhere exceeded the MPC. The significant pollution was observed in the Kirov district $(\mathrm{K} 0=3.8)$, in Zelenaia Roscha $(K 0=3.0)$ and Zaton $(K 0=2.1)$. In the second half of the summer, the same areas' hazard factors were equal: 3.8 , 1.8, 8.6, respectively. In Zaton, in individual samples, an excess of the MPC for the lead was observed by 16-22 times (Akhmetova St.). In the Kirov region, maximum pollution is recorded at the corner of Vorovskii St. and 81, Frunze St., 81 to 6.8 maximum concentration limits, and along 40, Pushkin St., - up to 6.7 maximum concentration limits. Other metals: increased zinc content in Zelenaia Roscha, Kirov District, and Zaton, respectively: 2.1; 1.8; 1.4 MPC in the spring. By the end of summer in the Kirov region 2.4 MPC, in Zaton 1.5 MPC, in Sipaylovo 1.5 MPC. There was an excess only in ZelenayaRoscha and Sipaylovo 1.2 MPC (average values) for a nickel.

The studies show that there was a decrease in soil pollution with volatile aromatic hydrocarbons during the study period, the concentration level of which is comparable with the MPC values. Ufa's soil pollution by heavy petroleum products is 2-36.5 times higher than their content in the control region - in the ShulganTash nature reserve of the Burzyan district. There is a ubiquitous presence of benzo(a)pyrene in the soil - from the reserve to Ufa's suburban zone, where 1.5 and 143 MPC respectively are determined.

The studies were conducted on various city sites, city parks, squares, and industrial sites of enterprises. The data are summarised and shown in Table 1.

The oil refining enterprises, petrochemical, chemical, and energy industries are concentrated mainly in the northern part. Table 1 shows that when moving from less polluted territories of water intake facilities to city squares, parks, beaches, and sections adjacent to highways, industrial enterprises of the northern part of Ufa, there is a significant excess concentration of HM soil. During the study, samples were taken, and analyzes were performed for the content of eight HM - Lead (Pb), Cadmium (Cd), Mercury (Hg), Zinc (Zn), Chromium (Cr), Arsenic (As), Selenium (Se), Cesium (Cs). According to Saet et al. (1990), the HM data are assigned to hazard classes 1 and 2 . The entire study area can be divided into five zones: residential (r), residential and transport $(\mathrm{r} / \mathrm{t})$, transport $(\mathrm{t})$, industrial (i), recreational (r), and water protection (w/p).

Soil sampling points are shown in Table 2.

Exceeding the MPC $\mathrm{Hg}$ throughout Ufa's entire city is not observed; the maximum value is $0.78 \mathrm{mg} / \mathrm{kg}$ on the ZolotyiePeski Beach in the Kirov District [3, 19].

No significant pollution of $\mathrm{Cd}$ and $\mathrm{Hg}$ was detected on Ufa's territory; however, taking into account the increased risk of environmental pollution due to the widespread use of new generation lighting fixtures, monitoring of mercury pollution is required. Throughout Ufa, samples were found that exceeded the MPC Cr, the average content was two times higher than the MPC, and the maximum was six times. The high toxicity of this metal creates the preconditions

Table 1. The analysis of soil samples for the content of HM, 1994.

\begin{tabular}{|c|c|c|c|c|c|}
\hline \multirow{2}{*}{ Place of selection } & \multirow{2}{*}{ Zone } & \multicolumn{4}{|c|}{ HM content in the soil, $\mathrm{mg} / \mathrm{dm}^{3}$} \\
\hline & & $\mathrm{Cu}$ & $\mathrm{Zn}$ & $\mathrm{Pb}$ & $\mathrm{Cd}$ \\
\hline $\begin{array}{c}\text { Water intake facilities } \\
\text { (conditionally background section) } \\
\text { - interval of change in the content of HM } \\
\text { Arithmetic average }\end{array}$ & $\mathrm{i}$ & $\begin{array}{c}28 \pm 6 \\
27.25 \pm 2.56\end{array}$ & $\begin{array}{c}81 \pm 9 \\
81.75 \pm 3.74\end{array}$ & $\begin{array}{c}7.6 \pm 2.8 \\
6.57 \pm 1.78\end{array}$ & $\begin{array}{c}0.61+0.64 \\
0.67 \pm 0.04\end{array}$ \\
\hline $\begin{array}{c}\text { City parks, squares, beaches: } \\
\text { - interval of change in the content of HM } \\
\text { Arithmetic average }\end{array}$ & $\mathrm{r}$ & $\begin{array}{c}36 \pm 17 \\
35.86 \pm 4.22\end{array}$ & $\begin{array}{c}140 \pm 50 \\
127.85 \pm 14.5\end{array}$ & $\begin{array}{c}10 \pm 7 \\
10.03 \pm 1.89\end{array}$ & $\begin{array}{c}0.6 \pm 0.4 \\
0.55 \pm 0.1\end{array}$ \\
\hline $\begin{array}{c}\text { City roads: } \\
\text { - interval of change in the content of HM } \\
\text { Arithmetic average }\end{array}$ & $\mathrm{t}$ & $\begin{array}{c}40 \pm 13 \\
39.5 \pm 2.82\end{array}$ & $\begin{array}{c}113 \pm 47 \\
112.0 \pm 9.6\end{array}$ & $\begin{array}{c}12 \pm 4 \\
12.02 \pm 0.95\end{array}$ & $\begin{array}{l}0.67 \pm 0.35 \\
0.65 \pm 0.08\end{array}$ \\
\hline $\begin{array}{c}\text { Oil refineries and thermal power plants: - interval of } \\
\text { change in the content of HM } \\
\text { Arithmetic average }\end{array}$ & $\mathrm{i}$ & $\begin{array}{c}42 \pm 18 \\
41.20 \pm 2.88\end{array}$ & $\begin{array}{c}165 \pm 75 \\
156.2 \pm 15.6\end{array}$ & $\begin{array}{c}19 \pm 13 \\
15.49 \pm 2.98\end{array}$ & $\begin{array}{c}0.9 \pm 0.6 \\
0.75 \pm 0.12\end{array}$ \\
\hline $\begin{array}{c}\text { OJSC „Ufahimprom” } \\
\text { - interval of change in the content of HM } \\
\text { Arithmetic average }\end{array}$ & $\mathrm{i}$ & $\begin{array}{c}50 \pm 20 \\
45.22 \pm 4.48\end{array}$ & $\begin{array}{c}240 \pm 150 \\
210.55 \pm 32.8\end{array}$ & $\begin{array}{c}20 \pm 15 \\
15.79 \pm 3.82\end{array}$ & $\begin{array}{c}0.944 \pm 0.64 \\
0.74 \pm 0.18\end{array}$ \\
\hline
\end{tabular}

Note: „l” is an industrial zone, „r" is a recreation zone, and „t” is a transport zone. 
Table 2. Points and location of soil sampling.

\begin{tabular}{|c|c|c|c|c|c|c|}
\hline Kirov district & Dema district & Lenin district & Soviet district & October district & $\begin{array}{l}\text { Ordzhonikidze } \\
\text { district }\end{array}$ & Kalinin district \\
\hline \multicolumn{7}{|c|}{ Points and location of soil sampling } \\
\hline $\begin{array}{c}\text { 1. Tram ring } \\
\text { “Zelenaya Ro- } \\
\text { scha" } 54.719039 \text {, } \\
56.006779\end{array}$ & $\begin{array}{l}\text { 5. Kolpinskai- } \\
\text { astr., maternity } \\
\text { hospital terri- } \\
\text { tory } \\
54.702742, \\
55.833592\end{array}$ & $\begin{array}{l}\text { 7. Crossing of Kra- } \\
\text { sin and Gafuri str. } \\
54.733994, \\
55.931954\end{array}$ & $\begin{array}{c}\text { 13. Crossing } \\
\text { f Mingazhev } \\
\text { and Ibragimov } \\
\text { str. } \\
54.739087, \\
55.973348\end{array}$ & $\begin{array}{c}\text { 15. Crossing of } \\
\text { 50-let SSSR and } \\
\text { October Avenue, } \\
\text { square } \\
54.755905, \\
56.004866\end{array}$ & $\begin{array}{c}\text { 17. Kalinin park } \\
54.797064 \\
56.040350\end{array}$ & $\begin{array}{l}\text { 28. Neftyanikov } \\
\text { Park } \\
54.817871 \\
56.090904\end{array}$ \\
\hline $\begin{array}{l}\text { 2. Crossing of } \\
\text { Validi and Vo- } \\
\text { rovskii str. } \\
54.715023 \\
55.957811\end{array}$ & $\begin{array}{l}\text { 6. Dema water } \\
\text { intake } \\
54^{\circ} 44^{\prime} 4^{\prime \prime} \mathrm{N} \\
55^{\circ} 53^{\prime} 17^{\prime} \mathrm{E}\end{array}$ & $\begin{array}{l}\text { 8. Over the Belaya } \\
\text { River bridge to } \\
\text { Zaton } \\
54.762543 \\
55.958662\end{array}$ & $\begin{array}{c}14 \text { Yakutov } \\
\text { park } \\
54.740082, \\
55.951218\end{array}$ & $\begin{array}{l}16 \text { Sipaylovo, } \\
\text { center, crossing } \\
\text { of Gagarin and } \\
\text { Rylskii str. } \\
54.767679, \\
56.071341\end{array}$ & $\begin{array}{c}18 \text { Kindergarten } \\
\text { territory, Tima- } \\
\text { shevo settlement } \\
54.837147, \\
56.148836\end{array}$ & $\begin{array}{l}\text { 29. Shaksha, } \\
\text { Selskaia str., } 4 \\
54.767679 \\
56.071341\end{array}$ \\
\hline $\begin{array}{l}\text { 3. Southern water } \\
\text { intake } \\
54^{\circ} 41^{\prime} 31^{\prime \prime} \mathrm{N} \\
56^{\circ} 1 \text { ' } 35^{\prime \prime} \mathrm{E} \\
\end{array}$ & & $\begin{array}{c}\text { 9. Beach "Sa- } \\
\text { fronovskaiapristan" } \\
54.760599 \\
55.975252 \\
\end{array}$ & & & $\begin{array}{l}19 \text { Left bank of } \\
\text { Chernushka river } \\
54^{\circ} 50^{\prime} 34^{\prime \prime} \mathrm{N} \\
56^{\circ} 8^{\prime} 14^{\prime \prime} \mathrm{E} \\
\end{array}$ & $\begin{array}{l}\text { 30. Northern water } \\
\text { intake } \\
54^{\circ} 49^{\prime} 1 \text { 'N } \\
56^{\circ} 13^{\prime} 10^{\prime \prime} \mathrm{E} \\
\end{array}$ \\
\hline \multirow[t]{8}{*}{$\begin{array}{l}\text { 4. Beach “Zolo- } \\
\text { tyiepeski” } \\
54.663745, \\
55.979634 \\
\end{array}$} & & $\begin{array}{l}\text { 10. Railway station } \\
54.747319, \\
55.949513\end{array}$ & & & $\begin{array}{c}20 \text { Landfillbe- } \\
\text { hindbitumenpits } \\
54.878833 \\
56.165737\end{array}$ & $\begin{array}{c}\text { 31. Inors, } \\
\text { Tsymlianski- } \\
\text { istr, } 24 \text { 54.773537, } \\
56.112585\end{array}$ \\
\hline & & $\begin{array}{l}\text { 11. Construction } \\
\text { Materials Plant } \\
54.745267 \\
55.911379\end{array}$ & & & 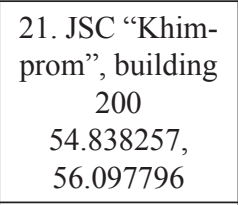 & $\begin{array}{c}\text { 32. Territory of } \\
\text { Thermal power } \\
\text { station-2 } \\
54.788286 \\
56.119340\end{array}$ \\
\hline & & $\begin{array}{c}\text { 12 School № } 22 . \\
\text { (Nizhegorodka) } \\
54.741680 \\
55.914042\end{array}$ & & & $\begin{array}{l}\text { 22. Industrial } \\
\text { Site Territory } \\
\text { JSC "Ufaorgsin- } \\
\text { tez" (north) } \\
54.890655 \text {, } \\
56.089256\end{array}$ & \\
\hline & & & & & $\begin{array}{c}\text { 23. Territory of } \\
\text { Thermal power } \\
\text { station-4 } \\
54.843637 \\
56.089149\end{array}$ & \\
\hline & & & & & $\begin{array}{c}24 \text { Terri- } \\
\text { tory of JSC } \\
\text { "Ufaneftekhim" } \\
54.925883, \\
56.073019\end{array}$ & \\
\hline & & & & & $\begin{array}{c}\text { 25. Territory of } \\
\text { Thermal power } \\
\text { station-3 } \\
54.869841 \\
56.090969\end{array}$ & \\
\hline & & & & & $\begin{array}{l}\text { 26. Territory of } \\
\text { JSC "Ufa Oil } \\
\text { processing plant" } \\
54.843974, \\
56.089163\end{array}$ & \\
\hline & & & & & $\begin{array}{c}\text { 27. Between } \\
\text { city landfill and } \\
\text { Kazanka village } \\
54.905204, \\
56.052062\end{array}$ & \\
\hline
\end{tabular}


for an in-depth study of the causes of increased soil pollution in Ufa. Particular attention should be paid to water protection zones, relatively prosperous for other studied components. It was found that the MPC exceeds the $\mathrm{Pb}$ content in the industrial zone in the territory of Ufakhimprom OJSC by 4.3 times. Exceeding the permissible content of $\mathrm{Zn}$ in the soil is established in places of heavy traffic and the zone of influence of the woodworking enterprise. $\mathrm{Zn}$ pollution is maximal in the residential zone, and city traffic flows and exceeds

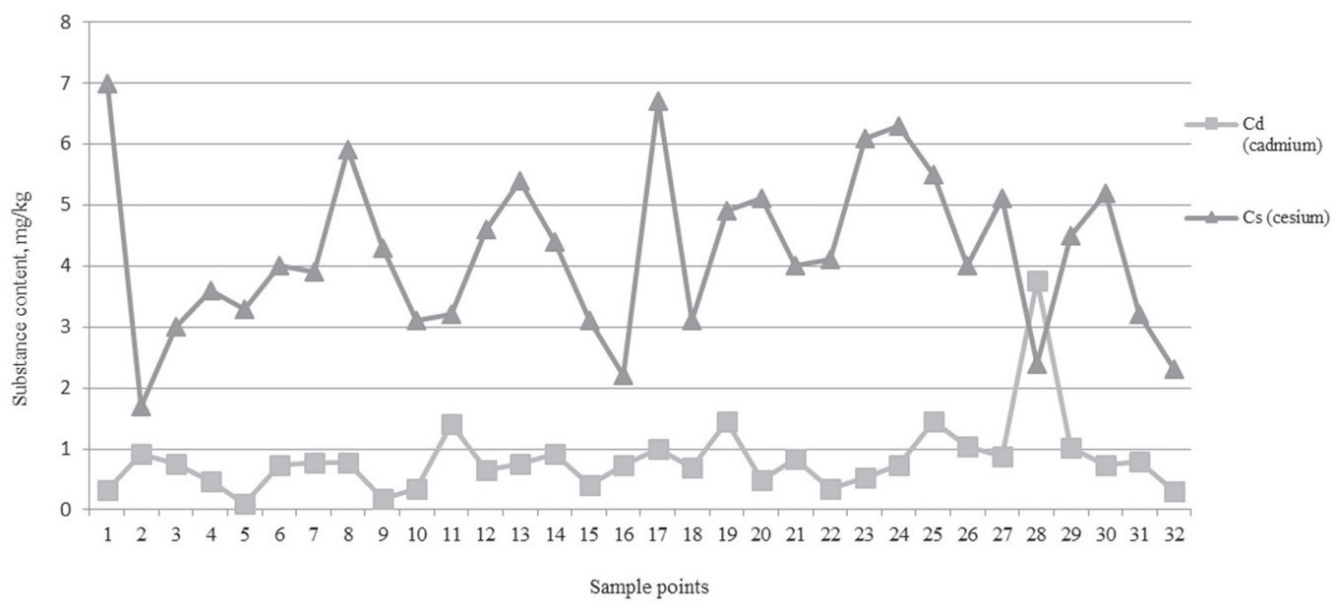

Fig. 1. Concentration of pollutants in soil samples in the range of $0-8.0 \mathrm{mg} / \mathrm{kg}$.

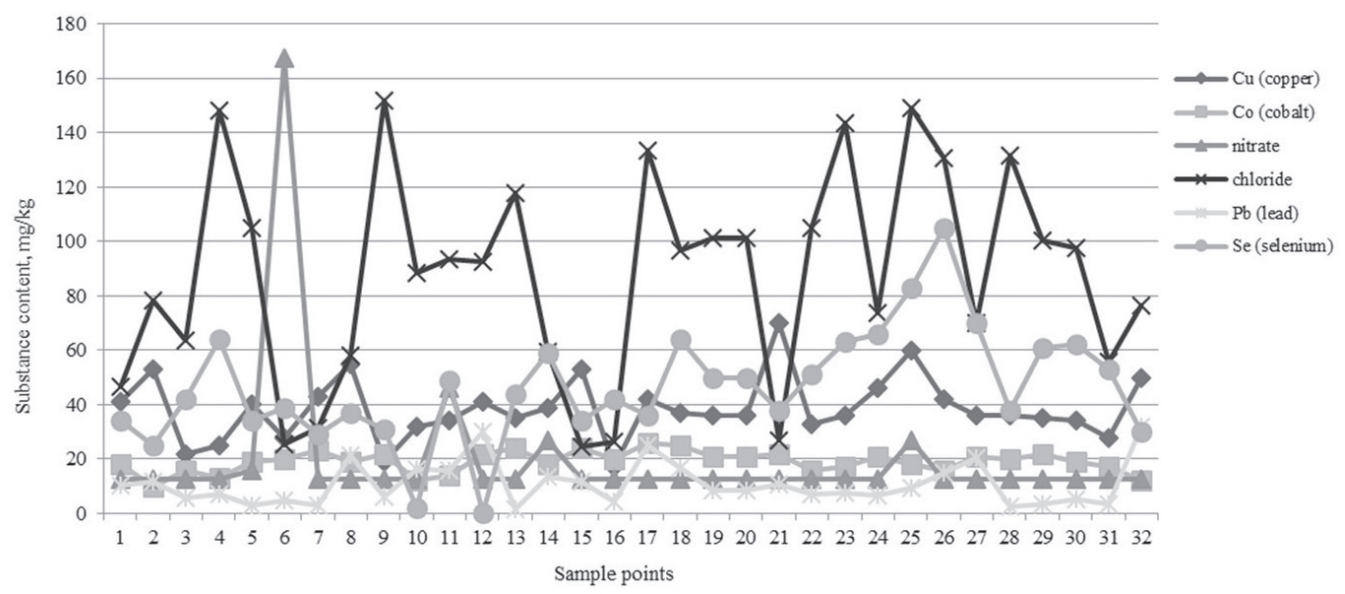

Fig. 2. Concentration of pollutants in soil samples in the range of $0-180.0 \mathrm{mg} / \mathrm{kg}$.

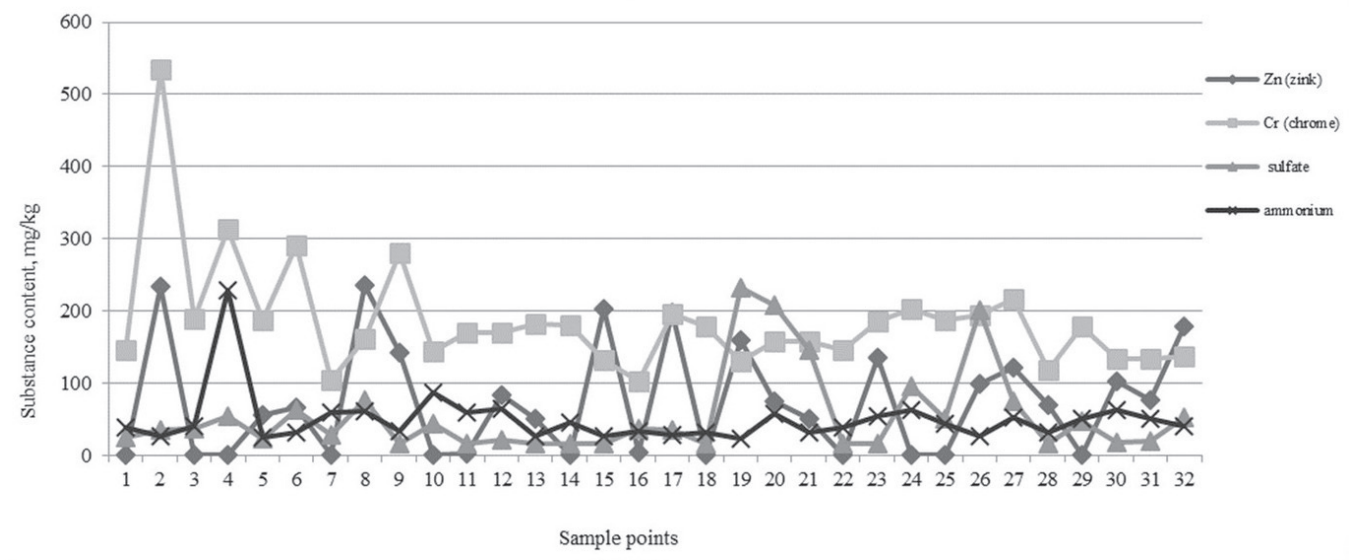

Fig. 3. Concentration of pollutants in soil samples in the range of $0-600.0 \mathrm{mg} / \mathrm{kg}$. 


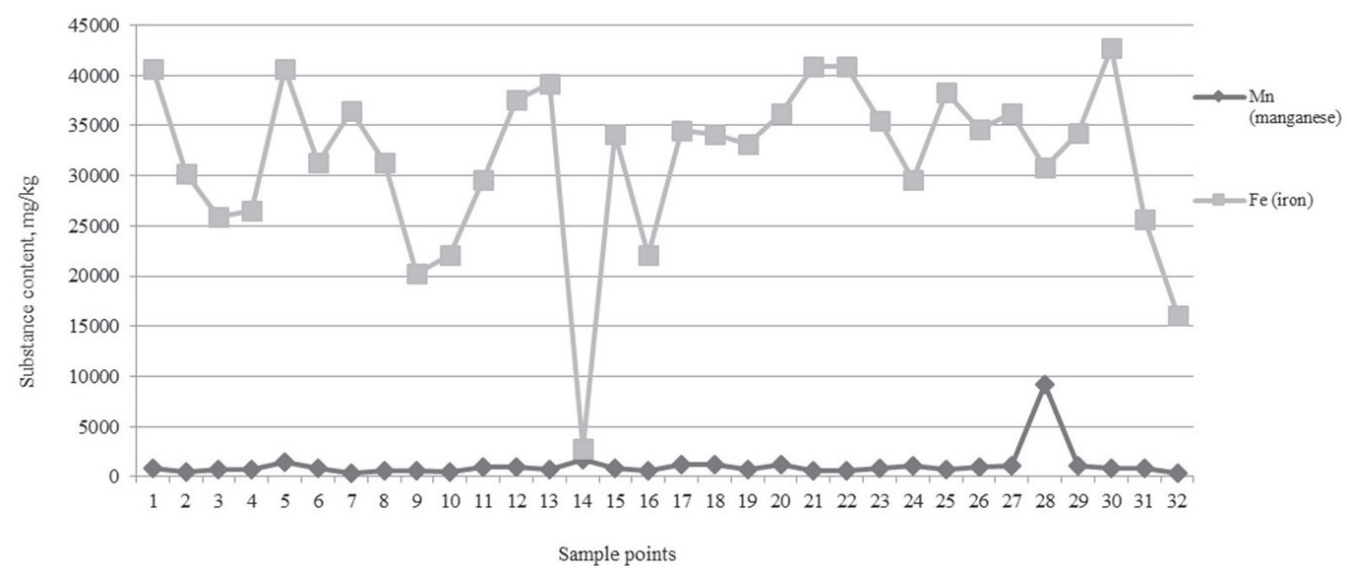

Fig. 4. Concentration of pollutants in soil samples in the range of $0-45000 \mathrm{mg} / \mathrm{kg}$.

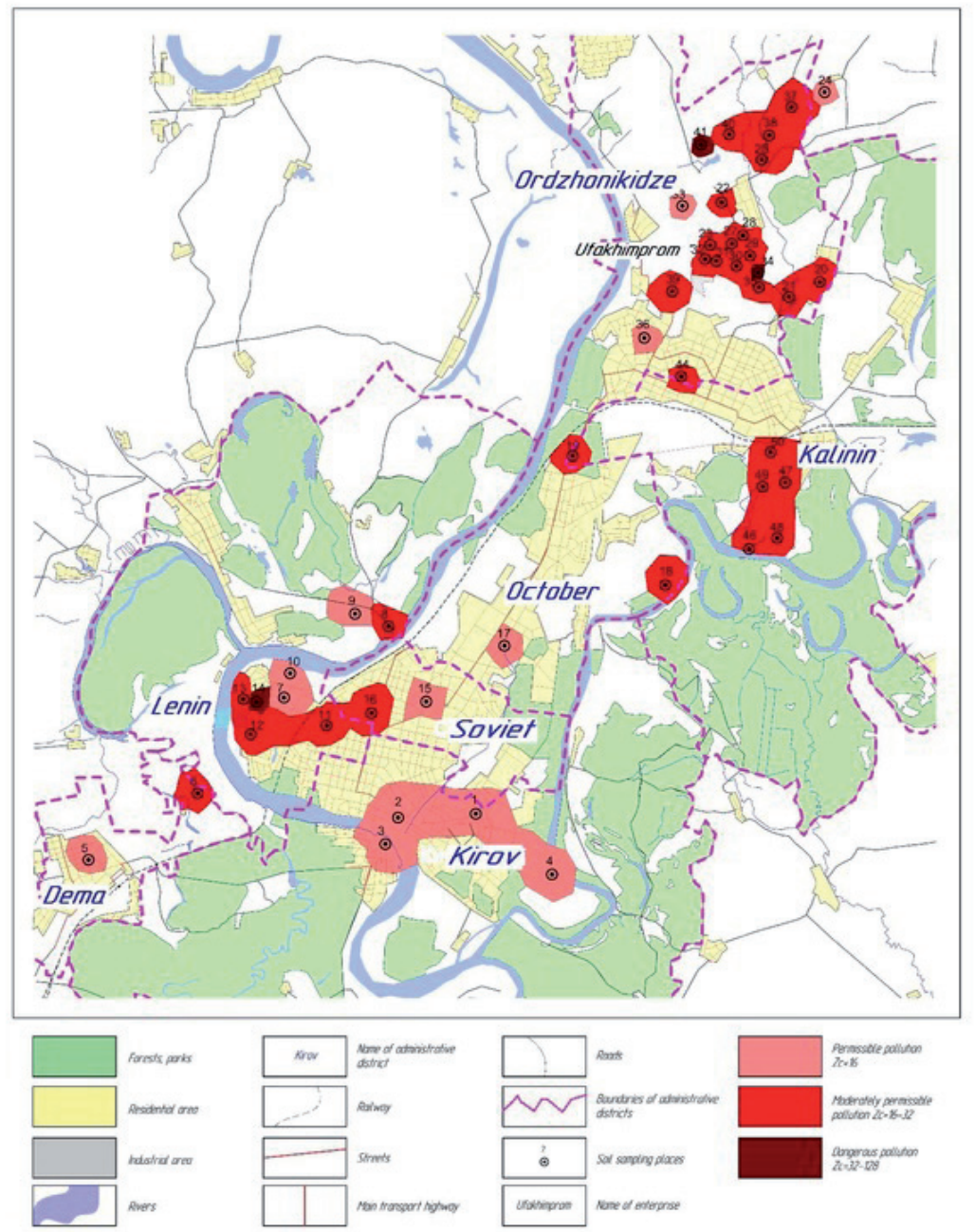

Fig. 5. Map of Ufa with sampling sites and a total pollution indicator Zc.

industrial zones' level. A significant level of $\mathrm{Cd}$ and $\mathrm{Cr}$ in recreational areas also requires the determination of pollution sources, rehabilitation of soil cover, and cleaning beaches. One of the reasons for pollution is sand washed in the Belaya River, near the industrial zones of Ufa [3, 19, 20].
Sample analysis results are shown in Figs 1-4.

In 2010, the State Unitary Enterprise Research Institute of Life Security staff in the Republic of Bashkortostan carried out an engineering and environmental survey of the most polluted territory of the city of Ufa - the industrial site of Ufakhimprom 
OJSC. It determined the content of organic pollutants in the soils.

Ten wells with $10 \mathrm{~m}$ were drilled, 100 soil samples, and ten groundwater samples were taken to determine pollutants' penetration depth into the lower soil horizons. Also, 155 point samples at a depth of 5-10 cm were taken from the enterprise's entire territory [21].

The soil of the territory of Ufahimprom OJSC is contaminated with chlorobenzenes $(14.3 \mathrm{~kg} / \mathrm{kg})$. The significant concentration is explained by the fact that the company was specialized in producing organochlorine synthesis products.

Also, the enterprise's territory is contaminated with heavy oil products; their concentration reaches $45.8 \mathrm{~kg} / \mathrm{kg}$.

The integrated assessment of the ecological state of soils in Ufa's city was carried out according to the methodology for assessing the level of chemical pollution of soils [26].

The result of an integrated assessment of the ecological state of soils in the city of Ufa is a map showing the total $\mathrm{Zc}$ indicator throughout the city (Fig. 5).

\section{Discussion}

The data from the study of the soil cover of Ufa's city are compared with the data from large industrial cities in the world. The soil studies of the cities of Colombo (Sri Lanka), the city of Annaba (Algeria), the city of Rio de Janeiro (Brazil), the city of Cairo (Egypt), and the city of Krakow (Poland) showed that the primary source of HM in the soil of cities is city transportation. In Russia, the most interesting are soil pollution studies by scientists Kosheleva N.E., Kasimov N.S., who have calculated the critical loads of benzo(a)pyrene on soils of the Eastern District of Moscow. It allows reliable prediction of the dynamics of soil pollution and the development of measures to clean them.

As for cadmium, its excess is observed in comparison with the background content. So, cadmium concentration in the recreational zones' soils ranged from 1 to $3.77 \mathrm{mg} / \mathrm{kg}$ with a background content of $0.3 \mathrm{mg} / \mathrm{kg}$. The amount of $1.58 \mathrm{mg} / \mathrm{kg}$ of cadmium was found in a soil sample taken on the Khimprom industrial site territory at workshop No. 31. At an old landfill near the territory of Khimprom OJSC, the concentration of cadmium was $1.46 \mathrm{mg} / \mathrm{kg}$; cadmium was also found in the soil of collective gardens (from 0.97 to $1.45 \mathrm{mg} / \mathrm{kg}$ ).

Of other metals, attention should be paid to the increased chromium content in soil samples; in the Kirov, Soviet, and Ordzhonikidze districts of the city, an increase in zinc and copper concentration was noted. The data obtained in the city of Ufa is consistent with the results of studies obtained in other world regions. Namely, soils experience the most technogenic load in large chemical, petrochemical, and energy industries, and near city streets with heavy traffic. The authors indicate $\mathrm{Cd}, \mathrm{Zn}, \mathrm{Pb}, \mathrm{Cu}, \mathrm{Cr}$, benzo(a)pyrene as elements with the most vital anthropogenic contribution.

\section{Conclusion}

Studies have shown that the development of industry and increased traffic have led to mechanical disturbance and pollution of the soil cover of Ufa's city with chemicals. This circumstance exacerbates the city's existing environmental disadvantage, leading to pollution of surface runoff, soil cover, groundwater, underground and surface water sources.

On the territory of the city of Ufa, there is an increase in the content of a carcinogenic substance hazardous to public health - benzo(a)pyrene and HM (lead, cadmium). The standards are significantly exceeded in the content of copper, zinc, chromium in the soil.

In the city of Ufa, benzo(a)pyrene was found everywhere in soil samples. Its content was higher than the MPC (20.9 and $27.7 \mathrm{mg} / \mathrm{kg}$ with a $\mathrm{MPC}=20 \mathrm{mg} / \mathrm{kg}$ ) in two of them. The widespread distribution of benzo(a)pyrene requires an in-depth study of this problem and the development of special measures to combat this environmental pollutant.

Lead and cadmium were also found in all samples, but their content was mainly lower than the MPC. Still, in one of the 32 samples studied (the territory of Khimprom OJSC), lead was detected in the amount of $138.48 \mathrm{mg} / \mathrm{kg}$ with an MPC of $32.0 \mathrm{mg} / \mathrm{kg}$ and one sample, also on the territory of the industrial site of JSC Khimprom, higher than the MPC $(35.76 \mathrm{mg} / \mathrm{kg})$. Although the cadmium content in all soil samples does not exceed the MPC, its content over almost the city's entire territory is higher than the background. It indicates the presence of technogenic pollution of the urban territory with cadmium.

\section{Conflict of Interest}

The authors declare no conflict of interest.

\section{References}

1. KABATA-PENDIAS A. Trace elements in soils and plants, $4^{\text {th }}$ edition. Taylor and Francis Group, LLC, London, 2011.

2. BJAMBASURJEN C., SHABANOVA E.V., KOROL'KOV A.T., VASIL'EVA I.E., OCHIRBAT G., HUUHJENHUU B. The distribution of trace elements in the soils of Ulan Bator. News of Irkutsk State University, Earth Science Series 26, 31, 2018.

3. KHAMITOV R.Z., MINIGAZIMOV N.S., CHUKTURIDI V.I. Study of pollution of the territory, surface, underground and drinking water in the city of Ufa with dioxins and other super toxicants. Research report. IAENM, Ufa, 1994. 
4. ZHU Y., TAO S., SUN J., WANG X., LI X., TSANG D.C. W., ZHU L., SHEN G., HUANG H., CAI C., LIU W. Multimedia modeling of the PAH concentration and distribution in the Yangtze River Delta and human health risk assessment. Sci. Total Environ. 647, 962, 2019.

5. RAI A.K., SINGH A.K., PATI J.K., GUPTA S., CHAKARVORTY M., NIYOGI A., PANDEY A., DWIVEDI M.M., PANDEY K., PRAKASH K. Assessment of topsoil contamination in an urbanized interfluve region of Indo-Gangetic Plains (IGP) using magnetic measurements and spectroscopic techniques. Environ. Monit. Assess. 191 (6), 1, 2019.

6. HERATH D., PITAWALA A., GUNATILAKE J., IQBAL M.C.M. Using multiple methods to assess heavy metal pollution in an urban city. Environ. Monit. Assess. 190 (11), 1, 2018.

7. BENSELHOUB A., KHARYTONOV M., BOUABDALLAH S., BOUNOUALA M., IDRES A., BOUKELLOUL M.-L. Bioecological assessment of soil pollution with heavy metals in Annaba (Algeria). Stud. Univ. Vasile Goldis Arad Stiint. Vietii 25 (1), 17, 2015.

8. GONZÁLEZ-MARTÍNEZ M.D., HUGUET C., PEARSE J., MCINTYRE N., CAMACHO L.A. Assessment of potential contamination of Paramo soil and downstream water supplies in a coal-mining region of Colombia. Appl. Geochem. 108, 104382, 2019.

9. BERNARDINO C.A.R., MAHLER C.F., SANTELLI R.E., FREIRE A.S., BRAZ B.F., NOVO L.A.B. Metal accumulation in roadside soils of Rio de Janeiro, Brazil: impact of traffic volume, road age, and urbanization level. Environ. Monit. Assess. 191 (3), 1, 2019.

10. SAID I., SALMAN S.A.E.R., SAMY Y., AWAD S.A., MELEGY A., HURSTHOUSE A.S. Environmental factors controlling potentially toxic element behavior in urban soils, El Tebbin, Egypt. Environ. Monit. Assess. 191 (5), $1,2019$.

11. MAZUREK R., KOWALSKA J.B., GĄSIOREK M., ZADROŻNY P., WIECZOREK J. Pollution indices as comprehensive tools for evaluation of the accumulation and provenance of potentially toxic elements in soils in Ojców National Park. J. Geochem. Explor. 201, 13, 2019.

12. KASIMOV N.S., KOSHELEVA N.E., NIKIFOROVA E.M., VLASOV D.V. Benzo[a]pyrene in urban environments of eastern Moscow: pollution levels and critical loads. Atmos. Chem. Phys. 17 (3), 2217, 2017.

13. MICHAEL P.S. Ecological impacts and management of acid sulphate soil. Asian J. Water Environ. Pollut. 10 (4), 13, 2013.

14. KASIMOV N.S. Methodology and Technique of landscapegeochemical analysis of cities. Ecogeochemistry of cities. Publishing house of MSU, Moscow, 1995.

15. KHAMALETDINOV R.R., GABITOV I.I., MUDARISOV S.G., KHASANOV E.R., MARTYNOV V.M., NEGOVORA A.V., STUPIN V.A., GALLYAMOV F.N., FARKHUTDINOV I.M., SHIROKOV D.Y. Improvement in Engineering Design of Machines for Biological Crop Treatment with Microbial Products. J. Eng. Appl. Sci. 13, 6500, 2018.

16. MUDARISOV S.G., GABITOV I.I., LOBACHEVSKY Y.P., MAZITOV N.K., RAKHIMOV R.S., KHAMALETDINOV R.R., RAKHIMOV I.R., FARKHUTDINOV I.M., MUKHAMETDINOV A.M., GAREEV R.T. Modeling the technological process of tillage. Soil Till. Res. 190, 70, 2019.

17. KOZLOV D.V., SIMONOVICH O.S., SNEZHKO V.L. The Failure Rate of Low-Head Ground Dams of Dangerous and Unsatisfactory Safety Level. Power Technol. Eng. 54, 343, 2020.

18. INTERSTATE COUNCIL FOR STANDARDIZATION, METROLOGY AND CERTIFICATION. Nature conservation. Soils. Classification of chemicals for pollution control. State Standard 17.4.1.02-83. Standartinform, Moscow, 2008.

19. BELAN L.N., AMIROVA Z.K., VALIULLINA A.U., SHAMSUTDINOVA L.R., HAKIMOVA A.A. Heavy metals in the soil of industrial, recreational and residential purposes in the city of Ufa. Bulletin of the Samara Scientific Center of the Russian Academy of Sciences 6, 169, 2015.

20. SAFONOV V.A. Biological Role of Selenium and Correction Effects of Its Content in the Organism of Animals. Geochem. Int. 56 (10), 1046, 2018.

21. KUTLIJAROV A.N., KUTLIJAROV D.N., KHAIDARSHINA E.T. On the problems and tasks of improving the quality of land in the Republic of Bashkortostan and ways to solve them. Land Management, Cadastre and Land Monitoring 3 (170), 14, 2019. 